\title{
INDEKS GLIKEMIK, BEBAN GLIKEMIK, KADAR PROTEIN, SERAT, DAN TINGKAT KESUKAAN KUE KERING TEPUNG GARUT DENGAN SUBSTITUSI TEPUNG KACANG MERAH
}

\author{
Annisa Istiqomah, Ninik Rustanti*) \\ Program Studi Ilmu Gizi Fakultas Kedokteran Universitas Diponegoro \\ J1.Dr.Sutomo No.18, Semarang, Telp (024) 8453708, Email : gizifk@ undip.ac.id
}

\begin{abstract}
Background: Type 2 Diabetes Mellitus closely related to the lifestyle. Nutritional strategy needed to control blood glucose to reduce the risk of complication. One of strategy is by choosing foods with low glycemic index (GI). Arrowroot and red bean contain high fiber, amylosa, resistant starch, and low GI. Utilization of arrowroot and red bean processed into cookies is purposed to produce snack with low GI.

Objective: To analyze the glycemic index, glycemic load, protein, fiber, and preference level of cookies arrowroot flour which substituted with red bean flour.

Methods: The completely randomized single factor experiment is on the concentration of red bean flour $10 \%, 15 \%$, $25 \%$, and 35\%) which substituted to the cookies. The glycemic index, glycemic load, protein, and fiber's data was analyzed by One Way ANOVA test continued with Tukey test, while preference level was analyzed by Friedman test. Result: Cookies with lowest IG was found on cookies with 35\% red bean flour substitution $(11,42)$. While cookies with lowest BG was found on cookies with $0 \%$ red bean flour substitution. Red bean flour substitution on cookies arrowroot flour had significant effect on protein, fiber content, and preference of colour, aroma, and taste, but had not effect on the texture.

Conclusion: All cookies formulation had low GI and GL. Much red bean flour substitution will increase protein and fiber content. Cookies with $25 \%$ red bean flour substitution more preferable than others.

Keyword: Cookies, red bean, arrowroot, glycemic index, protein, fiber, preference level.
\end{abstract}

\begin{abstract}
ABSTRAK
Latar belakang: Diabetes Melitus Tipe 2 berkaitan erat dengan pola hidup. Dalam penatalaksanaannya diperlukan kontrol gula darah untuk mengurangi risiko komplikasi. Salah satu upaya yang dapat dilakukan yaitu melalui pemilihan makanan ber-indeks glikemik (IG) rendah. Garut dan kacang merah mengandung tinggi serat, amilosa, pati resisten dan indeks glikemik rendah. Pemanfaatan garut dan kacang merah yang diolah menjadi kue kering diharapkan menghasilkan makanan selingan ber-IG rendah.
\end{abstract}

Tujuan: Menganalisis indeks glikemik, beban glikemik, kadar protein, serat, dan tingkat kesukaan kue kering garut dengan substitusi tepung kacang merah.

Metode: Penelitian eksperimental acak lengkap satu faktor yaitu empat variasi kadar tepung kacang merah $(0 \%$, $15 \%, 25 \%$, and 35\%) yang disubstitusikan pada kue kering. Data indeks glikemik, beban glikemik, kadar protein, dan serat dianalisis menggunakan One Way ANOVA dilanjutkan uji Tukey, sedangkan tingkat kesukaan dianalisis menggunakan uji Friedman.

Hasil: IG kue kering terendah yaitu pada substitusi tepung kacang merah 35\% (11,42). Sedangkan BG terendah pada substitusi tepung kacang merah 0\% (2,54). Substitusi tepung kacang merah berpengaruh nyata terhadap kadar protein, serat dan tingkat kesukaan warna, aroma, dan rasa, namun tidak berpengaruh terhadap tekstur.

Kesimpulan: Keempat formulasi kue kering memiliki IG dan BG rendah. Semakin banyak kadar tepung kacang merah, kadar protein dan serat semakin meningkat. Kue kering yang paling disukai berdasarkan uji kesukaan adalah kue kering dengan substitusi tepung kacang merah $25 \%$.

Kata Kunci: Kue kering, kacang merah, umbi garut, indeks glikemik, protein, serat, tingkat kesukaan

\section{PENDAHULUAN}

Diabetes Melitus (DM) adalah penyakit metabolisme yang merupakan suatu kumpulan gejala yang timbul pada seseorang karena adanya peningkatan kadar glukosa darah diatas normal (hiperglikemi). Hiperglikemi terjadi karena kelainan sekresi insulin, kerja insulin, atau keduanya. ${ }^{1} \quad$ Menurut International Diabetes Federation (IDF) pada tahun 2009, diperkirakan kenaikan jumlah penyandang DM di Indonesia dari
7,0 juta pada tahun 2009 menjadi 12,0 juta pada tahun 2030. ${ }^{2}$ Berdasarkan Riset Kesehatan Dasar tahun 2013 prevalensi DM pada usia > 15 tahun sebesar 6,9\%. ${ }^{3}$ DM Tipe 2 merupakan jenis penyakit diabetes yang paling banyak diderita dan berkaitan erat dengan pola hidup.

Modifikasi gaya hidup merupakan bagian penting dari manajemen diabetes yang bertujuan untuk meningkatkan kontrol gula darah sehingga dapat mengurangi risiko komplikasi. Salah satu cara 
untuk mengontrol gula darah adalah dengan pengaturan makan atau diet yang dapat dilakukan melalui pemilihan jumlah dan jenis karbohidrat yang tepat dengan menggunakan konsep Indeks Glikemik (IG). Indeks glikemik dapat memberikan petunjuk efek makanan terhadap kadar gula darah. Pangan dengan IG tinggi akan menaikkan kadar gula darah secara cepat, sedangkan pangan IG rendah menaikkan kadar gula darah dengan lambat. Indeks glikemik pangan dipengaruhi oleh banyak faktor antara lain kadar serat, perbandingan amilosa dan amilopektin, daya cerna pati, kandungan monosakarida, kadar lemak dan protein, cara pengolahan, serta zat anti gizi pangan. ${ }^{4}$

Salah satu bahan makanan yang mengandung tinggi serat, amilosa, pati resisten dan berindeks glikemik rendah adalah umbi garut. Indeks glikemik umbi garut paling rendah diantara umbi-umbi lain yaitu $14,{ }^{5}$ namun dalam proses pengolahan IG dapat berubah. Perbedaan metode dan proses pengolahan, karakteristik molekuler dan fisik granula pati dalam produk akhir dapat mempengaruhi nilai IG pangan. Berdasarkan penelitian terdahulu, pembuatan cookies dengan bahan dasar pati garut termodifikasi memiliki IG rendah yaitu 31 . Hal ini terjadi karena kadar pati resisten meningkat saat pengolahan, yaitu proses pemanggangan. ${ }^{6,7}$

Tepung garut berpotensi menjadi bahan pengganti terigu. Tepung garut memiliki kandungan protein sebesar $2,15 \%$, lemak $1,4 \%$, amilosa $25,94 \%$, dan serat larut 5,03\%. ${ }^{8}$ Kadar protein tepung garut cukup rendah sehingga untuk meningkatkan kadar protein dapat dilakukan dengan mengkombinasikan dengan bahan dari kacang-kacangan, seperti kacang merah.

Kacang merah merupakan pangan fungsional dengan kandungan lemak yang rendah namun tinggi serat, dan memiliki IG rendah yaitu 26, paling rendah diantara jenis kacang-kacangan. ${ }^{9}$ Dalam 100 gram kacang merah mengandung $17,37 \mathrm{~g}$ protein, $1,46 \mathrm{~g}$ lemak, dan 7,86 g serat yang terdiri atas serat larut sebesar 1,36 g dan serat tak larut sebesar 5,77 g. ${ }^{10,11}$ Pada penderita diabetes, serat larut yang mengikat air dan membentuk gel selama proses pencernaan berfungsi menangkap karbohidrat dan memperlambat penyerapan glukosa sehingga menurunkan kadar glukosa dalam darah. Berdasarkan penelitian, pemberian kacang merah sebesar $20 \%$ energi lebih efektif dalam menurunkan kadar gula darah pada tikus diabetes sebesar 69\%. Hal ini dikarenakan serat pangan dan pati resisten berpengaruh pada viskositas dan penyerapan gula sehingga berpotensi menurunkan gula darah. ${ }^{12}$

Produk roti-rotian dengan energi dan indeks glikemik rendah sudah mulai dikembangkan sebagai alternatif pangan untuk penderita diabetes melitus. Salah satunya adalah kue kering. Kue kering merupakan salah satu jenis makanan ringan yang mudah dijumpai dan disukai baik anak-anak maupun dewasa. Kombinasi tepung garut dan tepung kacang merah diharapkan dapat menghasilkan kue kering dengan nilai indeks glikemik rendah.

Disamping indeks glikemik, beban glikemik lebih mencerminkan respon glukosa secara keseluruhan. ${ }^{13,14}$ Beban glikemik (BG) dapat menilai dampak konsumsi karbohidrat yang mengandung indeks glikemik sehingga memberikan gambaran yang lebih lengkap dibandingkan hanya informasi indeks glikemik saja. Penelitian ini bertujuan untuk menganalisis nilai indeks glikemik, beban glikemik, kadar protein, serat, dan tingkat kesukaan kue kering tepung garut dengan substitusi tepung kacang merah sebagai makanan selingan pasien Diabetes Melitus Tipe 2.

\section{METODE}

Penelitian yang dilakukan termasuk dalam bidang food production yang dilakukan pada bulan Juni-Juli 2015. Uji protein dan serat dilakukan di Laboratorium Ilmu Gizi dan Teknologi Pangan Universitas Muhammadiyah Semarang dan di lingkup Universitas Diponegoro untuk menguji indeks glikemik dan tingkat kesukaan.

Penelitian ini merupakan penelitian dengan rancangan acak lengkap satu faktor, yaitu empat variasi kadar tepung kacang merah $(0 \%, 15 \%, 25 \%$, dan 35\%). Masing-masing kelompok dilakukan pengulangan sebanyak 3 kali dan dianalisis secara duplo. Berikut ini formulasi kue kering tepung garut dengan substitusi tepung kacang merah.

Tabel 1. Formulasi Substitusi Tepung Kacang Merah pada Kue Kering Tepung Garut

\begin{tabular}{ccc}
\hline Perlakuan & Tepung Garut & $\begin{array}{c}\text { Substitusi Tepung Kacang } \\
\text { Merah }\end{array}$ \\
\hline T0 & $100 \%$ & $0 \%$ \\
T1 & $85 \%$ & $15 \%$ \\
T2 & $75 \%$ & $25 \%$ \\
T3 & $65 \%$ & $35 \%$ \\
\hline
\end{tabular}


Kue kering dibuat menggunakan bahan baku tepung garut dengan merk "Hasil Bumiku", tepung kacang merah merk "Gasol", gula DM (sorbitol 1,97 g dan sukralosa 9,8 mg), kuning telur, dan margarin. Cara pembuatan kue kering adalah margarin dan gula dikocok menggunakan mixer, kemudian ditambahkan kuning telur, lalu dikocok hingga homogen. Setelah itu ditambahkan tepung garut dan tepung kacang merah, campur adonan hingga merata, lalu adonan dicetak dan dipanggang dalam oven selama 20 menit dengan suhu $200^{\circ} \mathrm{C}$.

Pada penelitian utama, data yang dikumpulkan adalah indeks glikemik, beban glikemik, kadar protein, serat, dan tingkat kesukaan. Perhitungan IG menggunakan metode Incremental Area Under the Blood Glucose Response Curve (IAUC). ${ }^{15}$ Pengujian ini menggunakan 6 orang subjek dengan karakteristik subjek yaitu, rata-rata umur 21 tahun, berat badan 44,30 kg, tinggi badan $152,5 \mathrm{~cm}$, IMT $19,10 \mathrm{~kg} / \mathrm{m}^{2}$, dan glukosa darah puasa $78 \mathrm{mg} / \mathrm{dL}$. Sehari sebelum perlakuan subjek diharuskan berpuasa (kecuali air putih) selama 10 jam mulai pukul 22.00 sampai 08.00 pagi berikutnya. Kemudian subjek diminta untuk mengonsumsi pangan uji (glukosa murni dan kue kering tepung garut dengan substitusi tepung kacang merah $0 \%, 15 \%, 25 \%$, dan $35 \%$ ) yang mengandung 50 gram available carbohydrate. Sampel darah diambil setiap 30 menit (menit ke-30, 60, 90, dan 120) setelah mengonsumsi pangan uji selama 2 jam. Setiap perlakuan diberi jarak 3 hari untuk menghindari bias dari setiap perlakuan. Uji IG dilakukan menggunakan alat tes glukosa merk Autocheck produksi General Life Biotechnology Co.Ltd.,. Data hasil kemudian ditebar pada sumbu $\mathrm{X}$ sebagai waktu dan sumbu Y sebagai kadar gula darah. Besar IG dihitung dengan membandingkan luas daerah bawah kurva pangan uji dan pangan standar, kemudian hasilnya dirata-rata.

Perhitungan BG dilakukan dengan mengkalikan IG dengan kandungan karbohidrat per porsi kue kering tepung garut dengan substitusi tepung kacang merah yang didapatkan dari hasil uji total gula dan pati kemudian dibagi 100. Sementara zat gizi yang diamati meliputi kadar protein dengan metode Makro Kjeldahl, dan kadar serat dengan metode gravimetri. Uji tingkat kesukaan dilakukan untuk mengetahui tingkat kesukaan panelis terhadap kue kering garut substitusi tepung kacang merah menggunakan uji hedonik dengan lima skala hedonik, $1=$ tidak suka, $2=$ agak tidak suka, 3= netral, 4= agak suka, 5= suka. Uji kesukaan dilakukan pada 25 panelis agak terlatih (mahasiswa Ilmu Gizi Universitas Diponegoro) dengan skala penilaian 1-5 yaitu mulai dari tidak suka sampai suka. Data IG, BG, kadar protein, dan serat dianalisis menggunakan One Way ANOVA dilanjutkan uji Tukey, sedangkan tingkat kesukaan dianalisis menggunakan uji Friedman dan dilanjutkan dengan Wilcoxon.

\section{HASIL \\ Indeks Glikemik (IG) Kue Kering}

Kue kering tepung garut dengan substitusi tepung kacang merah 35\% memiliki IG terendah yaitu $11,42 \%$. Hasil analisis statistik menunjukkan bahwa substitusi tepung kacang merah tidak berpengaruh terhadap penurunan nilai indeks glikemik. Indeks glikemik masing-masing kue kering tepung garut dengan substitusi tepung kacang merah dapat dilihat pada Tabel 2.

Tabel 2. Indeks Glikemik Kue Kering Tepung Garut Substitusi Tepung Kacang Merah

\begin{tabular}{ccc}
\hline Perlakuan & $\begin{array}{c}\text { Indeks Glikemik } \\
(\%)\end{array}$ & Kategori* \\
\hline Substitusi 0\% & $16,06 \pm 10,02$ & Rendah \\
Substitusi 15\% & $14,05 \pm 7,56$ & Rendah \\
Substitusi $25 \%$ & $12,65 \pm 6,10$ & Rendah \\
Substitusi 35\% & $11,42 \pm 8,81$ & Rendah \\
\hline
\end{tabular}

*Kategori: IG rendah $(<55)$, IG sedang $(55-70)$, IG tinggi $(>70)$

\section{Beban Glikemik (BG)}

Nilai BG kue kering tepung garut dengan substitusi tepung kacang merah yaitu antara 2,54 3,38. Semakin tinggi kadar tepung kacang merah, BG kue kering akan meningkat. Hasil analisis statistik nilai $\mathrm{BG}$ menunjukkan bahwa substitusi tepung kacang merah pada kue kering garut tidak berpengaruh terhadap penurunan BG. Hasil perhitungan BG secara singkat dapat dilihat pada Tabel 3. 
Tabel 3. Beban Glikemik Kue Kering Tepung Garut Substitusi Tepung Kacang Merah

\begin{tabular}{|c|c|c|c|c|c|}
\hline Perlakuan & $\begin{array}{c}\text { Jumlah } \\
\text { penyajian } \\
(\mathrm{g})\end{array}$ & $\begin{array}{c}\text { Available } \\
\text { Carbohydrate } \\
(\mathrm{g})\end{array}$ & $\begin{array}{c}\text { Available } \\
\text { Carbohydrate/porsi }\end{array}$ & $\begin{array}{c}\text { Beban } \\
\text { Glikemik* }\end{array}$ & Kategori** \\
\hline Substitusi $0 \%$ & 25 & 63,32 & 15,83 & $2,54 \pm 1,59$ & Rendah \\
\hline Substitusi $15 \%$ & 25 & 82,40 & 20,60 & $2,89 \pm 1,56$ & Rendah \\
\hline Substitusi $25 \%$ & 25 & 102,71 & 25,68 & $3.25 \pm 1,57$ & Rendah \\
\hline Substitusi $35 \%$ & 25 & 118,19 & 29,55 & $3,38 \pm 2,05$ & Rendah \\
\hline & & & & $\mathrm{p}=0,868$ & \\
\hline
\end{tabular}

\section{Kadar Protein}

Hasil uji kadar protein kue kering tepung garut dengan substitusi tepung kacang kacang merah yang memiliki kadar protein tertinggi adalah kue kering dengan substitusi tepung kacang merah $35 \%$. Secara keseluruhan kadar protein meningkat seiring dengan meningkatnya substitusi tepung kacang merah. Hasil uji statistik menunjukkan bahwa substitusi tepung kacang merah meningkatkan kadar protein kue kering tepung garut secara bermakna $(\mathrm{p}=0,000)$. Hasil analisis kadar protein kue kering tepung garut dengan substitusi tepung kacang merah secara singkat dapat dilihat pada Tabel 4

Tabel 4. Hasil Analisis Protein Kue Kering Tepung Garut dengan Substitusi Tepung Kacang Merah

\begin{tabular}{cc}
\hline Substitusi Tepung Kacang Merah & Kadar Protein $(\%)$ \\
\hline $0 \%$ & $3,26 \pm 0,46^{\mathrm{d}}$ \\
$15 \%$ & $7,46 \pm 0,88^{\mathrm{c}}$ \\
$25 \%$ & $10,00 \pm 0,93^{\mathrm{b}}$ \\
$35 \%$ & $13,75 \pm 1,20^{\mathrm{a}}$ \\
\hline & $\mathrm{p}=0,000$ \\
\hline gan: Angka yang diikuti huruf superscript berbeda $(\mathrm{a}, \mathrm{b}, \mathrm{c}, \mathrm{d})$ menunjukkan beda nyata
\end{tabular}

\section{Kadar Serat Kasar}

Hasil uji statistik menunjukkan bahwa substitusi tepung kacang merah meningkatkan kadar serat kasar kue kering tepung garut secara bermakna $(p=0,000)$. Hasil analisis serat kasar kue kering tepung garut dengan substitusi tepung kacang merah secara singkat dapat dilihat pada Tabel 5.

Tabel 5. Hasil Analisis Kadar Serat Kasar Kue Kering Garut dengan Substitusi Tepung Kacang Merah

\begin{tabular}{cc}
\hline Substitusi Tepung Kacang Merah & Kadar Serat Kasar (\%) \\
\hline $0 \%$ & $0,62 \pm 0,75^{\mathrm{d}}$ \\
$15 \%$ & $1,40 \pm 0,04^{\mathrm{c}}$ \\
$25 \%$ & $1,89 \pm 0,03^{\mathrm{b}}$ \\
$35 \%$ & $2,20 \pm 0,74^{\mathrm{a}}$ \\
\hline \multicolumn{2}{c}{ Keterangan: Angka yang diikuti huruf superscript berbeda $(\mathrm{a}, \mathrm{b}, \mathrm{c}, \mathrm{d})$} \\
\cline { 2 - 2 } \\
\cline { 2 - 2 }
\end{tabular}

\section{Tingkat Kesukaan}

Hasil analisis uji kesukaan kue kering tepung garut substitusi tepung kacang merah terhadap warna, rasa, aroma, dan tekstur secara singkat dapat dilihat pada Tabel 6 .

Tingkat penerimaan panelis terhadap warna kue kering tepung garut dengan substitusi tepung kacang merah antara 2,76 4,04 . Kue kering tepung garut dengan substitusi tepung kacang merah 15\%, 25\%, dan 35\% dapat diterima oleh panelis dengan tingkat kesukaan agak suka, sedangkan pada substitusi $0 \%$ dinilai netral. Berdasarkan uji lanjut Wilcoxon, kue kering dengan substitusi tepung kacang merah $15 \%, 25 \%$, dan $35 \%$ memiliki perbedaan bermakna dengan kue kering tepung garut substitusi tepung kacang merah $0 \%$.

Hasil analisis tingkat kesukaan terhadap rasa kue kering tepung garut dengan substitusi tepung kacang merah menunjukkan bahwa substitusi tepung kacang merah $35 \%$ memiliki 
tingkat kesukaan paling tinggi dengan rerata 4,12. Berdasarkan uji lanjut Wilcoxon, kue kering tepung garut dengan substitusi tepung kacang merah $0 \%$ berbeda bermakna dengan kue kering tepung garut substitusi tepung kacang merah $15 \%, 25 \%$, dan $35 \%$.

Tabel 6. Hasil Analisis Kesukaan Kue Kering Tepung Garut dengan Substitusi Tepung Kacang Merah

\begin{tabular}{|c|c|c|c|c|c|c|c|c|}
\hline \multirow{2}{*}{ Subst } & \multicolumn{2}{|c|}{ Warna } & \multicolumn{2}{|c|}{ Rasa } & \multicolumn{2}{|c|}{ Aroma } & \multicolumn{2}{|c|}{ Tekstur } \\
\hline & Rerata & Ket & Rerata & Ket & Rerata & Ket & Rerata & Ket \\
\hline $0 \%$ & $2,76 \pm 1,33^{\mathrm{d}}$ & Netral & $2,20 \pm 1,26^{\mathrm{d}}$ & $\begin{array}{l}\text { Agak } \\
\text { tidak } \\
\text { suka }\end{array}$ & $3,32 \pm 1,13^{\mathrm{c}}$ & Netral & $3,20 \pm 1,47$ & Netral \\
\hline $15 \%$ & $3,92 \pm 1,12^{\mathrm{c}}$ & $\begin{array}{l}\text { Agak } \\
\text { suka }\end{array}$ & $3,80 \pm 1,41^{\mathrm{b}}$ & $\begin{array}{l}\text { Agak } \\
\text { suka }\end{array}$ & $3,40 \pm 1,41^{\mathrm{c}}$ & Netral & $3,52 \pm 1,26$ & $\begin{array}{l}\text { Agak } \\
\text { suka }\end{array}$ \\
\hline $25 \%$ & $4,04 \pm 1,06^{\mathrm{ac}}$ & $\begin{array}{c}\text { Agak } \\
\text { suka }\end{array}$ & $4,12 \pm 1,33^{\mathrm{ab}}$ & $\begin{array}{c}\text { Agak } \\
\text { suka }\end{array}$ & $4,08 \pm 1,08^{\mathrm{a}}$ & $\begin{array}{c}\text { Agak } \\
\text { suka }\end{array}$ & $3,44 \pm 1,47$ & Netral \\
\hline \multirow[t]{2}{*}{$35 \%$} & $3,92 \pm 1,11^{\mathrm{abc}}$ & $\begin{array}{l}\text { Agak } \\
\text { suka }\end{array}$ & $3,44 \pm 1,32^{\mathrm{abc}}$ & Netral & $3,96 \pm 1,06^{\mathrm{ab}}$ & $\begin{array}{l}\text { Agak } \\
\text { suka }\end{array}$ & $3,36 \pm 1,9$ & Netral \\
\hline & \multicolumn{2}{|c|}{$\mathrm{p}=0,000$} & \multicolumn{2}{|c|}{$\mathrm{p}=0,000$} & \multicolumn{2}{|c|}{$\mathrm{p}=0,040$} & \multicolumn{2}{|c|}{$\mathrm{p}=0,989$} \\
\hline
\end{tabular}

Keterangan: Angka yang diikuti huruf superscript berbeda (a, b, c, d) menunjukkan beda nyata

Substitusi tepung kacang merah pada kue kering tepung garut berpengaruh terhadap aroma. Pada Tabel 6 dapat dilihat bahwa tingkat kesukaan aroma kue kering tepung garut tertinggi yaitu dengan substitusi tepung kacang merah $25 \%$ dan tingkat kesukaan paling rendah pada kue kering dengan substitusi tepung kacang merah $0 \%$.

Tekstur kue kering dengan tepung garut dengan substitusi tepung kacang merah cenderung netral, hanya pada substitusi $15 \%$ yang dinilai agak suka. Pada Tabel 6 diketahui bahwa nilai rerata tingkat kesukaan panelis terhadap tekstur yaitu 3,20 - 3,52. Secara statistik, substitusi tepung kacang merah pada kue kering tepung garut tidak memiliki perbedaan yang signifikan.

\section{PEMBAHASAN}

\section{Indeks Glikemik dan Beban Glikemik}

Berdasarkan respon glikemiknya pangan dibedakan menjadi 3 kelompok, yaitu pangan IG rendah $(<55)$, IG sedang (55-70), dan IG tinggi $(>70) .{ }^{4}$ Berdasarkan pengelompokan tersebut, kue kering tepung garut dengan substitusi tepung kacang merah 35\% memiliki IG terendah yaitu $11,42 \%$. Penurunan IG dapat disebabkan oleh banyak faktor, diantaranya adalah kadar serat, kadar protein dan lemak, serta cara pengolahan. ${ }^{4}$

Serat akan mempengaruhi IG pangan dengan cara meningkatkan viskositas, memberikan rasa kenyang yang lebih lama dan menurunkan absorpsi makronutrien sehingga akan menurunkan glukosa darah postprandial dan insulin. Semakin banyak substitusi tepung kacang merah pada kue kering tepung garut maka kadar serat meningkat. Hal ini menyebabkan IG kue kering semakin menurun. Sementara bahan pangan dengan kandungan protein tinggi cenderung memiliki IG rendah karena laju pengosongan lambung menjadi lambat, sehingga pencernaan dan kenaikan glukosa darah menjadi lambat. Namun, kadar protein tidak memiliki pengaruh yang cukup besar terhadap indeks glikemik walaupun mempunyai potensi untuk menurunkan nilai IG pangan. Selain komponen kimia kacang merah, proses pengolahan juga dapat menyebabkan retrogradasi, tingginya kandungan amilosa dan pati resisten pada kacang merah, yaitu $30,47 \mathrm{~g}$ dan $10,63 \mathrm{~g}{ }^{16,17}$ menyebabkan kacang merah dicerna lebih lambat sehingga dapat digunakan untuk mengontrol kadar gula darah.

Pangan dengan IG rendah akan dicerna dan diubah menjadi glukosa secara bertahap dan perlahan-lahan, sehingga puncak kadar gula darah juga akan rendah, dan fluktuasi peningkatan kadar gula relatif pendek. Apabila seseorang mengkonsumsi pangan tinggi IG maka akan memicu sekresi insulin lebih banyak daripada makanan dengan IG rendah karena terjadi hiperglikemia postprandial dan meningkatnya level incretin, ${ }^{18}$ yaitu hormon yang berperan dalam stimulasi sekresi insulin, sehingga terjadi hiperinsulinemia yang menyebabkan resistensi insulin. Oleh karena itu, pada penderita DM Tipe 2 dianjurkan mengkonsumsi makanan dengan IG rendah dan mengurangi konsumsi pangan dengan IG tinggi agar kadar gula darahnya dapat dikontrol. Tujuannya adalah untuk mengurangi BG pangan secara keseluruhan.

Beban glikemik memberikan informasi yang lebih lengkap mengenai pengaruh konsumsi pangan aktual terhadap peningkatan kadar gula darah. Jika menggunakan IG, informasi yang didapat hanya menggambarkan kecepatan perubahan karbohidrat menjadi gula darah, tetapi tidak memberikan gambaran berapa banyak 
karbohidrat yang terdapat di dalam makanan tersebut. Beban glikemik dikategorikan menjadi tiga, yaitu BG rendah $(\leq 10)$, BG sedang (11-19), dan $\mathrm{BG}$ tinggi $(\geq 20){ }^{19}$

Berdasarkan hasil penelitian, BG kue kering tepung garut dengan substitusi tepung kacang merah $0 \%, 15 \%, 25 \%$, dan $35 \%$ berturutturut yaitu 2,$54 ; 2,89 ; 3,25$; dan 3,38. Semakin banyak substitusi tepung kacang merah maka BG semakin meningkat, hal ini disebabkan kandungan total pati dan gula juga meningkat. Meskipun demikian, keempat formulasi kue kering masih tergolong dalam kategori $\mathrm{BG}$ rendah $(<10)$. BG rendah dan diet $\mathrm{BG}$ telah menunjukkan perbaikan dalam kontrol glikemik, penurunan serum lipid, risiko kardiovaskular dan diabetes. ${ }^{20} \mathrm{Hal}$ tersebut diperkuat dengan hasil penelitian di Jepang, yang menyimpulkan terdapat hubungan antara diet tinggi BG dengan risiko DM Tipe 2 pada wanita. ${ }^{21}$

\section{Kadar Protein}

Substitusi tepung kacang merah mempengaruhi kadar protein kue kering tepung garut $(p=0,000)$. Semakin banyak kadar tepung kacang merah pada kue kering tepung garut menyebabkan kadar protein meningkat. Hal ini dikarenakan tepung kacang merah memiliki kadar protein yang lebih tinggi, yaitu 22,85\% ${ }^{22}$ dibandingkan dengan tepung garut yang hanya memiliki kandungan protein sebesar 2,15\%. ${ }^{8}$ Oleh karena itu, dengan dilakukan substitusi maka jumlah tepung garut berkurang sehingga kadar protein kue kering meningkat. Kue kering tepung garut dengan substitusi tepung kacang merah 15\% mengalami peningkatan protein sebesar $4,2 \%$, substitusi $25 \%$ mengalami peningkatan $6,74 \%$, dan substitusi $35 \%$ mengalami peningkatan $10,49 \%$.

Protein berperan dalam pembentukan jaringan yang rusak dan membantu pertumbuhan sel. ${ }^{23}$ Konsumsi protein bernilai biologis tinggi dapat meningkatkan penyerapan dan penggunaan nitrogen, sehingga mengurangi sisa hasil metabolisme protein dalam tubuh dan tidak memperberat ginjal penderita DM Tipe $2 .{ }^{24}$ Perhitungan protein dari makanan selingan yang dianjurkan untuk penderita DM Tipe 2 yaitu $20 \%$ dari kebutuhan kalori makanan selingan, sehingga didapatkan kandungan protein sebesar $10 \mathrm{~g} .{ }^{2}$ Hasil uji kandungan protein kue kering yaitu 3,26-13,75 g/100 g. Konsumsi kue kering dengan substitusi tepung kacang merah $35 \%$ sebanyak $25 \mathrm{~g}$ dapat memenuhi kebutuhan protein sebesar 34,38\% dari kebutuhan makanan selingan. Berdasarkan penelitian, diet tinggi protein $(30 \%)$ dapat menurunkan gula darah postprandial dan meningkatkan kontrol gula darah pada penderita
DM Tipe $2 .{ }^{25}$ Kadar protein yang tinggi dalam pangan dapat memicu sekresi insulin, meningkatkan uptake glukosa dan penggunaan glukosa oleh jaringan sehingga glukosa dalam darah tidak berlebih dan dapat dikendalikan. ${ }^{4}$

Kacang merah juga mengandung arginin, yaitu $600 \mathrm{mg} / 100 \mathrm{~g} .{ }^{26}$ Arginin berperan sebagai antidiabetik yaitu regenerasi sel $\beta$ pankreas untuk meningkatkan stimulasi sekresi insulin. ${ }^{27}$ Arginin sebagai asam amino terminal hormonal GLP-1 (Glucagon-Like-Peptide-1) berfungsi merangsang ekspresi gen pro-insulin dan sintesis insulin. Setelah terjadi sekresi insulin maka kadar glukosa di sirkulasi segera menurun, dengan demikian efek GLP-1 akan hilang dengan sendirinya.

\section{Serat Kasar}

Kadar serat kasar kue kering tepung garut dengan substitusi tepung kacang merah mengalami peningkatan dibandingkan dengan kadar serat kue kering tepung garut kontrol. Kue kering garut dengan substitusi tepung kacang merah $15 \%$ mengalami peningkatan serat $0,78 \%$, substitusi $25 \%$ mengalami peningkatan $1,27 \%$, dan substitusi $35 \%$ mengalami peningkatan $1,58 \%$. Berdasarkan analisis statistik, substitusi tepung kacang merah pada kue kering tepung garut berbeda secara signifikan terhadap kadar serat kasar.

Kenaikan kadar serat kasar pada kue kering tepung garut disebabkan karena adanya substitusi tepung kacang merah. Kandungan serat tak larut pada kacang merah yaitu sebesar 5,77 g. ${ }^{11}$ Serat kasar merupakan seperlima bagian dari serat pangan. Serat kasar nilainya rendah karena $\mathrm{H}_{2} \mathrm{SO}_{4}$ $1,25 \%$ dan $\mathrm{NaOH} 1,25 \%$ mempunyai kemampuan yang lebih besar untuk menghidrolisis dibandingkan dengan enzim pencernaan.

Asupan serat yang dianjurkan untuk penderita DM Tipe 2 adalah sebesar $25 \mathrm{~g} /$ hari. ${ }^{1}{ }^{K}$ Kue kering dengan substitusi tepung kacang merah $35 \%$ per 25 g kue kering dapat menyumbang 2,2\% dari anjuran kebutuhan serat per hari. Pada penderita DM, serat kasar akan mempertebal kerapatan dan ketebalan campuran makanan pada saluran pencernaan dan menghambat pergerakan enzim sehingga proses pencernaan menjadi lambat dan respon gula menjadi lebih rendah. ${ }^{4,28}$

\section{Tingkat kesukaan}

Substitusi tepung kacang merah mempengaruhi tingkat kesukaan warna kue kering tepung garut dengan substitusi tepung kacang merah. Hasil penilaian kue kering yang disubstitusi dengan tepung kacang merah adalah agak suka (3,92 - 4,04). Hal ini karena panelis menyukai kue kering dengan warna yang agak coklat. Semakin tinggi kadar tepung kacang merah semakin gelap 
dan pucat warna yang dihasilkan sehingga substitusi tepung kacang merah sebanyak 35\% menurunkan kesukaan panelis karena warna yang dihasilkan terlalu gelap yang berasal dari bintik-bintik warna kacang merah. Sementara panelis menilai netral pada kue kering tepung garut substitusi tepung kacang merah $0 \%$ karena warna yang dihasilkan kuning cerah.

Berdasarkan uji tingkat kesukaan, nilai rata-rata terhadap rasa kue kering tepung substitusi tepung kacang merah $15 \%, 25 \%$, dan $35 \%$, yaitu 3,80-4,12 (agak suka) sedangkan penilaian pada substitusi $0 \%$ yaitu agak tidak suka. Pada umumnya, peningkatan kadar tepung kacang merah pada kue kering tepung garut akan meningkatkan kesukaan rasa. Namun, pada substitusi tepung kacang merah terbanyak terjadi penurunan kesukaan, hal ini disebabkan rasa dari kue kering terlalu berserat dan rasa dari kacang merah lebih kuat. Sedangkan pada kontrol, panelis tidak menyukai rasanya karena masih ada rasa hambar dari umbi garut. Kue kering yang paling disukai panelis adalah kue kering dengan substitusi tepung kacang merah $25 \%$. Rasa khas dari kacang-kacangan merupakan salah satu faktor yang harus diperhatikan karena akan menentukan daya terima konsumen. ${ }^{29}$

Peran aroma dalam makanan sangat penting karena akan menentukan daya terima konsumen. Berdasarkan hasil uji kesukaan, aroma kue kering tepung garut dengan substitusi tepung kacang merah cenderung meningkat. Semakin banyak kadar tepung kacang merah yang ditambahkan aroma khas kacang merah semakin muncul. Hal tersebut yang menyebabkan panelis lebih menyukai aroma kue kering. Panelis lebih menyukai kue kering dengan substitusi tepung kacang merah $25 \%$.

Uji kesukaan tekstur kue kering tepung garut dengan substitusi tepung kacang merah cenderung netral. Meskipun demikian, panelis lebih menyukai kue kering dengan substitusi tepung kacang merah 15\% dengan kategori agak suka. Semakin banyak substitusi tepung kacang merah, maka tekstur kue kering akan semakin keras. Tekstur suatu produk berkaitan dengan kadar air dan kadar protein dimana semakin tinggi kadar protein maka akan semakin menyerap air sehingga tekstur yang dihasilkan semakin kokoh. ${ }^{29}$

\section{SIMPULAN}

Keempat formulasi kue kering memiliki indeks glikemik dan beban glikemik rendah. Kue kering tepung garut dengan substitusi tepung kacang merah $35 \%$ memiliki indeks glikemik terendah $(11,42 \%)$ dengan beban glikemik tertinggi $(3,38)$. Semakin banyak kadar tepung kacang merah pada kue kering tepung garut, kandungan protein dan serat kasar semakin meningkat. Kue kering tepung garut dengan substitusi tepung kacang merah yang paling disukai adalah substitusi $25 \%$.

\section{SARAN}

Kue kering yang direkomendasikan adalah kue kering tepung garut dengan substitusi tepung kacang merah $25 \%$ yang memiliki IG $12,65 \%$, BG 3,25 dengan kandungan protein $2,5 \mathrm{~g}$, dan serat 0,47 g per $25 \mathrm{~g}$ kue kering. Perlu dilakukan penelitian lebih lanjut mengenai efek pemberian kue kering tepung garut dengan substitusi tepung kacang merah terhadap kadar gula darah penderita DM Tipe 2.

\section{DAFTAR PUSTAKA}

1. American Diabetes Association. Diagnosis and Classification of Diabetes Mellitus. Diabetes care [Internet]. 2012 Jan [cited 2014 Oct 21];35 Suppl 1:S64-71. Available from: http://www.pubmedcentral.nih.gov/articlerender.fc gi $?$ artid $=3632174 \&$ tool $=$ pmcentrez\&rendertype $=\mathrm{a}$ $\underline{\text { bstract }}$

2. Perkumpulan Endokrinologi Indonesia. Konsensus Pengelolaan dan Pencegahan Diabetes Melitus Tipe 2 di Indonesia. Jakarta: Perkeni. 2011.

3. Badan Penelitian dan Pengembangan Kesehatan. Riset Kesehatan Dasar. Jakarta: Kemenkes RI. 2013.

4. Rimbawan dan A Siagian. Indeks Glikemik Pangan. Jakarta: Penebar Swadaya; 2004.

5. Hasan V, S Astuti, dan Susilawati. Indeks Glikemik Oyek dan Tiwul dari Umbi Garut (Marantha arundinaceae L.), Suweg (Amorphallus campanullatus BI), dan Singkong (Manihot utillisima). J Teknologi Industri dan Hasil Pertanian. Maret 2011;16(1).

6. Gustiar H. Sifat Fisiko-Kimia dan Indeks Glikemik Produk Cookies Berbahan Baku Pati Garut (Maranta arundinacea L) Termodifikasi. [Skripsi]. Bogor: Institut Pertanian Bogor Fakultas Teknologi Pertanian. 2009.

7. Sajilata MG, RS Singhai, and PR Kulkarni. Resistent Starch: A Review. Comprehensive Reviews Food Science and Food Safety. 2006;5.

8. Wirabrata IK, Supriyanto, dan U Purwandari. Optimasi Penggunaan Tepung Garut dalam Pembuatan Fried Batter Coating dengan Penambahan Carboxymethyl Cellulose (CMC). Seminar Nasional Kedaulatan Pangan dan Energi; Juni 2012.

9. Marsono $\mathrm{Y}, \mathrm{P}$ Wiyono, dan $\mathrm{Z}$ Noor. Indeks Glisemik Kacang-Kacangan. J Teknologi dan Industri Pangan. 2002;13(3).

10. Sai-Ut S, S Ketnawa, P Chaiwut, and S Rawdkuen. Biochemical and Functional Properties of Proteins from Red Kidney, Navy and Adzuki Beans. As. J. Food Ag-Ind. 2009;2(04):493-504. 
11. Li BW, KW Andrews, and P Pehrsson. Individual Sugars, Soluble, and Insoluble Dietary Fiber Contents of 70 High Consumption Food. J Food Composition and Analysis. 2002;15:715-723.

12. Marsono Y, Z Noor, F Rahmawati . Pengaruh Diet Kacang Merah Terhadap Kadar Gula Darah Tikus Diabetik Induksi Alloxan. J Teknologi dan Industri Pangan. 2003;14(1).

13. Thomas D, E Ej. Low Glycaemic Index , or Low Glycaemic Load, Diets For Diabetes Mellitus (Review). JAMA. 2009;(3).

14. Bator E, M Bronkowska, M Bienkiewicz, and J Biernat. The Impact of the Glycemic Index and Glycemic Load of Food Products on Human Health. J Medical Science. 2014;2(83).

15. The Role of Glycemic Index in Food Choice. In : Carbohydrates in Human Nutrition. Rome : FAO. 1998. [diakses pada tanggal 13 Mei 2015. Available from URL

http://www.fao.org/docrep/w8079e/w8079e0a.htm \#TopOfPage.

16. Moongngarm A. Chemical Compositions and Resistant Starch Content in Starchy Foods. American J Agricultural Bio Sci. 2013;8(2): $107-$ 113)

17. Fuentes-Zaragosa E, MJ Riquelme-Navarrete, E Sanches-Zapata, and JA Perez-Alvarez. Resistant Starch as Functional Ingredient: A review. Food Research International. 2010 .

18. Ludwig D. The Glycemic Index Physiological Mechanism Relating to Obesity, Diabetes, and Cardiovaskular Disease. American Med Association. 2002;287(18).

19. Ningrum DR, FZ Nisa, dan R Pangestuti. Indeks Glikemik dan Beban Glikemik Sponge Cake Sukun Sebagai Jajanan Berbasis Karbohidrat pada Subjek Bukan Penyandang Diabetes Melitus. Skripsi. Yogyakarta: Universitas Gajah Mada. 2011.

20. Fernandez-raudales D, LK Diaz-rios, J Lotton, and K Chapman-novakofski. Effect of Beverages With Different Protein Profiles on Postprandial Blood Glucose Response in Overweight and Obese Men. J Diabetes Mellitus. 2012;2(1):40-6.

21. Oba Shino, et.al. Dietary Glycemic Index, Glycemic Load, and Incidence of Type 2 Diabetes in Japanese Men and Women: the Japan Public Health Center-Based Prospective Study. Nutr J. 2013;12(165).

22. Ningrum MRB. Pengembangan Produk Cake dengan Substitusi Tepung Kacang Merah. Skripsi. Yogyakarta: Universitas Negeri Yogyakarta. 2012.

23. Franz MJ. Medical Nutrition Therapy for Diabetes Mellitus and Hypoglycemia of Nondiabetic Origin. IN: Mahan LK, Stump SE. Krause's Food and the Nutrition Care Process 13th edition. Philadephia: WB Saunders Company; 2012.

24. Gallagher ML. The Nutrient and Their Metabolism. In: Mahan LK, Stump SE, editors. Krause's Food and the Nutrition Care Process 13th edition.
Philadelphia: WB Saunders Company; 2012. p. 3241.

25. Gannon MC, FQ Nuttal, A Saeed, K Jordan, H Hoover. An Increase in Dietay Protein Improves the Blood Glucose Response in Persons with Type 2 Diabetes. Am J Clin Nutr. 2003; 78:734-41.

26. Audu SS, and MO Aremu. Effect of Processing on Chemical Composition of Red Kidney Bean ( Phaseolus vulgaris L .) Flour. Pakistan J Nutr. 2011;10(11):1069-75.

27. Monti LD, MC Casiraghi, E Setola, E Galluccio, MA Pagani, L Quaglia, et al,. L-Arginin Enriched Biscuit Improve Endothelial Function and Glucose Metabolism: A Pilot Study in Healthy Subjects and A Cross-over Study in Subjects with Impaired Glucose Tolerance and Metabolic Syndrome. Metabolism Clinical and Experimental. 2013;62: 255-264.

28. Jenkins DJA, CWC Kendall, A Marchie, AL Jenkins, LSA Augustin, DS Ludwig, et al. Type 2 diabetes and the vegetarian diet $1-4$. Am J Clin Nutr. 2003;78:610-6.

29. Manonmani D, S Bhol, and SJD Bosco. Effect of Red Kidey Bean (Phaseolus vulgaris L.) Flour on Bread Quality. Open Access Library Jornal. 2014:1. 